\section{ADditions tO ASTERINACEOUS (ASCOMYCETES) FUNGI IN INDIA}

\section{V.B. Hosagoudar ${ }^{1}$, A. Sabeena ${ }^{2}$ \& Sam P. Mathew ${ }^{3}$}

1,2,3 Jawaharlal Nehru Tropical Botanic Garden and Research Institute, Palode, Thiruvananthapuram, Kerala 695562, India

${ }^{1}$ vbhosagoudar@rediffmail.com (corresponding author), ${ }^{2}$ asabeenarasheed@ gmail.com; ${ }^{3}$ sampmatthew@rediffmail.com

Asterinaceous fungi are commonly known as black mildews and are characterized by their black colonies formed on green leaves, produce thyriothecia, which dehisce either vertically or stellately at the centre. These fungi are being extensively studied in the tropics (Theissen 1913; Hansford 1946; Müller \& Arx 1962; Hosagoudar \& Abraham 2000; Hofmann \& Piepenbring 2008) and this group has been revised by Hosagoudar (2012) for India.

\section{Asterina arkemibeyi sp. nov.}

(Fig. 1) (MycoBank \# 802279)

Materials examined: Holotype: TBGT 6003, 29.i.2012, on leaves of Flacourtia montana Graham (Flacourtiaceae), Kallara, Thiruvananthapuram, Kerala, India, coll. A. Sabeena.

Colonies hypophyllous, thin to subdense, up to $2 \mathrm{~mm}$ in diameter, confluent. Hyphae flexuous, branching opposite to alternate at acute to wide angles, loosely reticulate, cells $16-27 \times 3-4 \mu \mathrm{m}$. Appressoria unicellular, mostly alternate, often sub-opposite to opposite, narrowly ovate, elongated, tubular, entire to sublobate, straight to variously curved, $6-13 \times 3-5 \mu \mathrm{m}$. Thyriothecia scattered to connate, orbicular, up to $130 \mu \mathrm{m}$ in diameter, margin crenate to fimbriate, stellately dehisced at the centre; asci, octosporous, globose, up to $30 \mu \mathrm{m}$ in diameter; ascospores, conglobate, 1-septate, constricted at the septum, $17-20 \times 7-10 \mu \mathrm{m}$, wall smooth.

Hofmann \& Piepenbring (2008) showed the connection between Mahanteshamyces (Hosag.) and

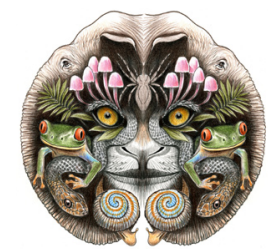

ISSN

Online 0974-7907 Print 0974-7893

\section{OPEN ACCESS} Asterina Lév. The former genus is an anamorph of the latter. The present collection reveals both anamorph and teleomorph in the same

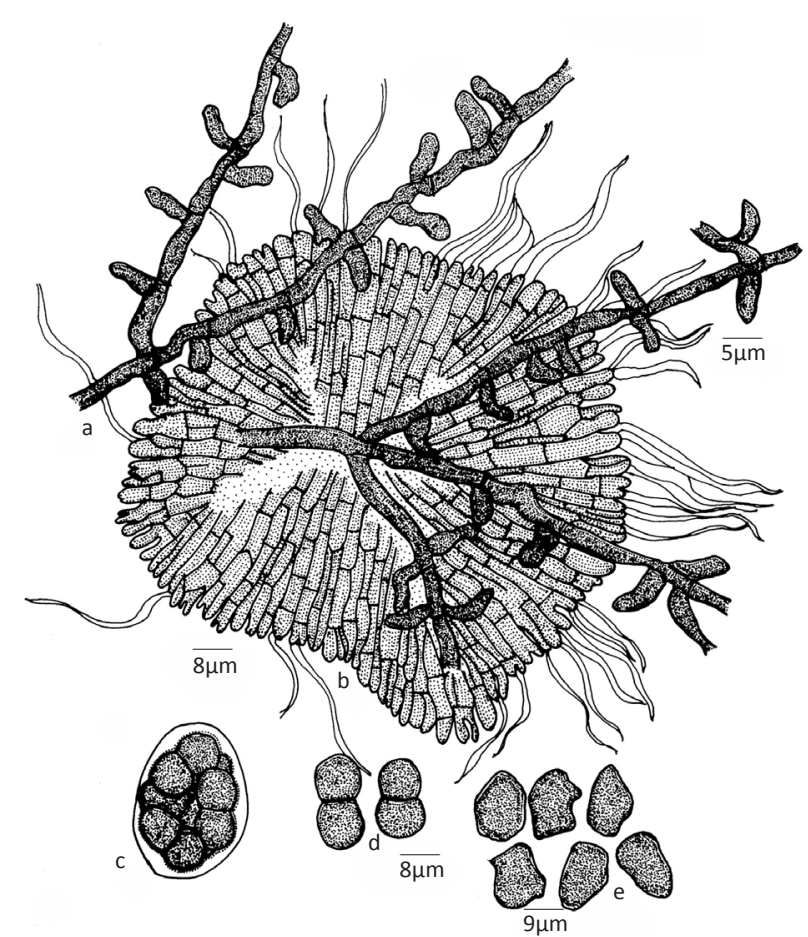

Figure 1. Asterina arkemibeyi sp. nov.

a - Appressoriate mycelium; b - Thyriothecium; c - Ascus;

d - Ascospores; e - Pycnothyriospores

DOI: http://dx.doi.org/10.11609/JoTT.03228.3670-72

Editor: R.K. Verma, Tropical Forest Research Institute, Jabalpur, India.

Date of publication: 26 February 2013 (online \& print)

Manuscript details: Ms \# 03228 | Received 31 May 2012 | Final received 13 November 2012 | Finally accepted 02 February 2013

Citation: Hosagoudar, V.B., A. Sabeena \& S.P. Mathew (2013). Additions to asterinaceous fungi (Ascomycetes) in India. Journal of Threatened Taxa 5(2): 3670-3672; doi:10.11609/JoTT.03228.3670-72.

Copyright: @ Hosagoudar et al. 2013. Creative Commons Attribution 3.0 Unported License. JoTT allows unrestricted use of this article in any medium, reproduction and distribution by providing adequate credit to the authors and the source of publication.

Funding: None.

Competing Interest: None.

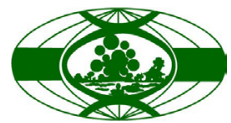

Acknowledgements: We are grateful to Dr. P.G. Latha, Director, Jawaharlal Nehru Tropical Botanic Garden and Research Institute, Palode for the facilities. 
colonies, which supports and confirms the observations of Hofmann \& Piepenbring (2008). The teleomorph belongs to the genus Asterina and differs from the all known Asterina species on the members of the family Flacourtiaceae in having ovate, elongated, tubular, entire to sublobate and straight to variously curved appressoria (Hosagoudar \& Abraham 2000; Hosagoudar 2012).

Etymology: This species is named in honour of Prof. Richard K. Mibey, who contributed to this group from Kenya.

\section{Asterina derridicola sp. nov.}

(Fig. 2) (MycoBank \# 802280)

Materials examined: Holotype: TBGT 6004, 21.iii.2012, on leaves of Derris sp. (Fabaceae), Chozhiyakode, Kollam, Kerala, India, coll. V.B. Hosagoudar et al. Isotype: TBGT 6006.

Colonies epiphyllous, subdense to dense, up to $4 \mathrm{~mm}$ in diameter, confluent. Hyphae substraight to undulate, branching opposite to alternate at acute to wide angles, loosely reticulate, cells 22-40x4-5 $\mu \mathrm{m}$. Appressoria unicellular, alternate, globose to ovate, entire, 7-12x7-

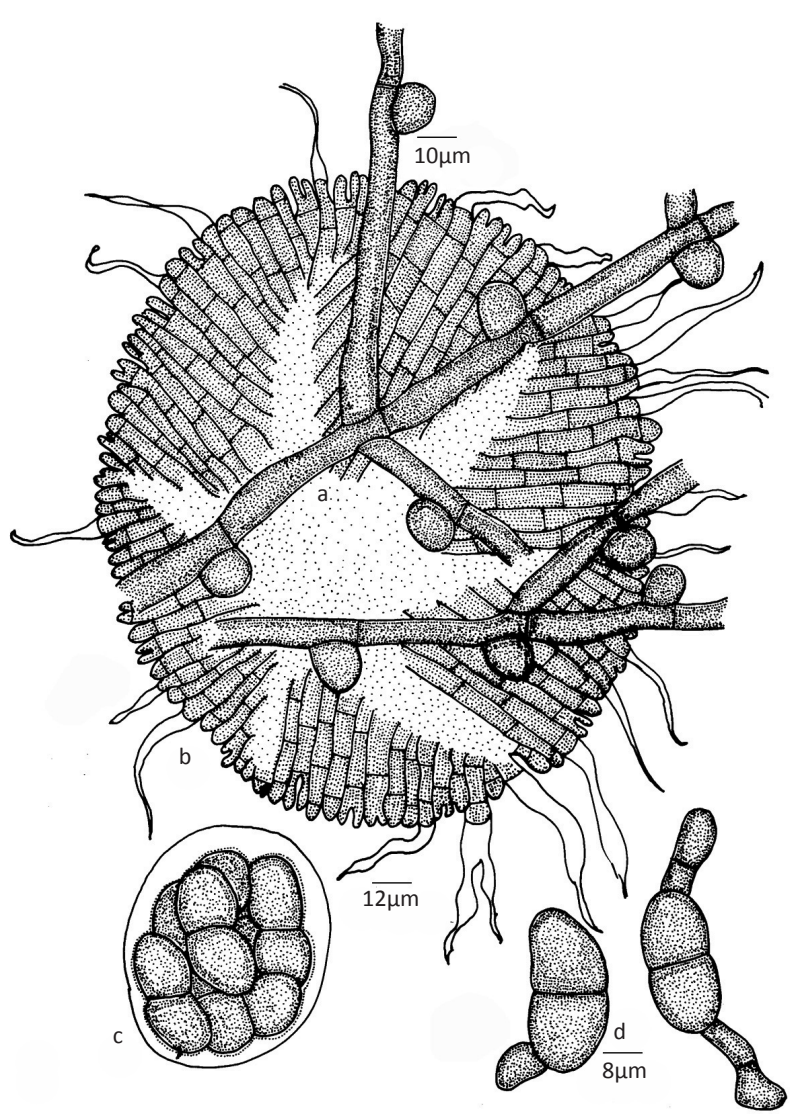

Figure 2. Asterina derridicola sp. nov.

a - Appressoriate mycelium; b - Thyriothecium; c - Ascus;

d-Ascospores
$10 \mu \mathrm{m}$. Thyriothecia scattered to connate, orbicular, up to $170 \mu \mathrm{m}$ in diameter, stellately dehisced at the centre, margin crenate to fimbriate, fringed hyphae flexuous; asci globose, octosporous, up to $42 \mu \mathrm{m}$ in diameter; ascospores, oblong, conglobate, 1-septate, constricted at the septum, 30-35×12-15 $\mu \mathrm{m}$, wall smooth.

Asterina derridis P. Henn. (Theissen 1913), A. trachycarpa Syd. \& P. Syd. (Sydow \& Sydow 1912) and $A$. singaporensis Syd. \& P. Syd. (Sydow \& Sydow 1920) are known species on Derris from Singapore and Philippines. However, the present species differs from these in having epiphyllous colonies, ovate to globose appressoria and distinctly larger ascospores.

The specific epithet is based on the host genus

Viegasia cissampeli (Hansf.) Bat.

(Fig. 3)

Atas Inst. Micol. Univ. Recife 1: 305, 1960.

Schneepia cissampeli Hansf., Proc. Linn. Soc. London 151:194, 1946.

Materials examined: 29.i.2012, on leaves of Cissampelos pareira L. (Menispermaceae), Kallara, Thiruvananthapuram, Kerala, India, coll. A. Sabeena TBGT 6005 .

Colonies epiphyllous, subdense to dense, up to 3 $\mathrm{mm}$ in diameter. Hyphae crooked, branching irregular at acute angles, cells $16-27 \times 2-3 \mu \mathrm{m}$. Appressoria rare, unicellular, globose, entire to sublobate, 5-6x5-8 $\mu \mathrm{m}$. Thyriothecia connate, up to $140 \mu \mathrm{m}$ in diameter, dehisced

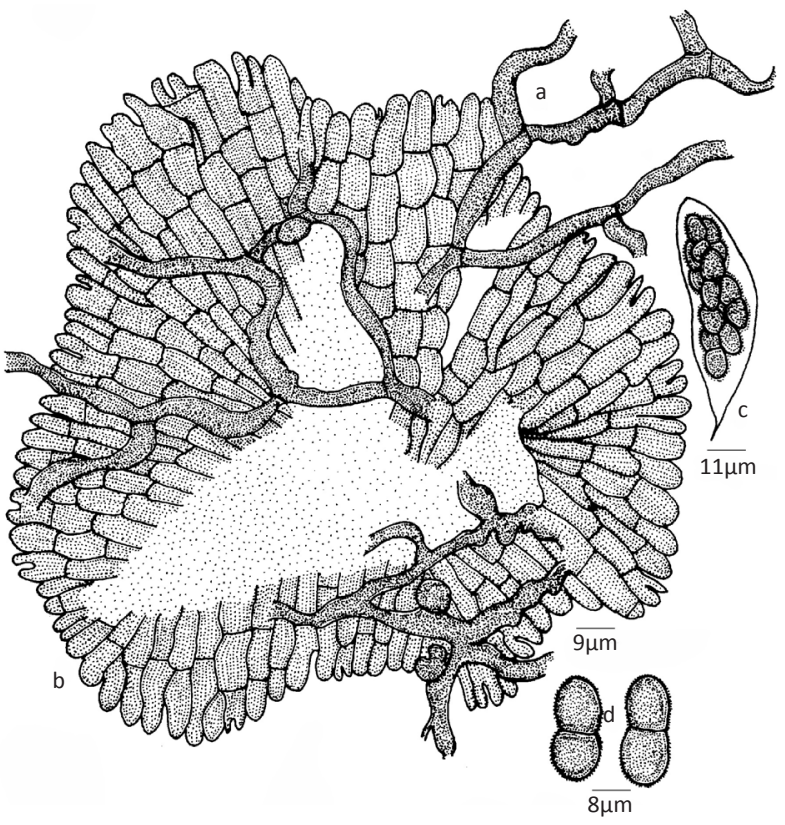

Figure 3. Viegasia cissampeli (Hansf.) Bat.

a - Appressoriate mycelium; b - Thyriothecium; c - Ascus;

d - Ascospores; e - Pycnothyriospores 
centrally; asci octosporous, globose, ovate, up to $20 \mu \mathrm{m}$ in diameter; ascospores, brown, conglobate, 1-septate, constricted at the septum, 14-21x5-9 $\mu \mathrm{m}$, wall slightly verrucose.

Closely scattered, orbicular thyriothecia, mycelium without appressoria but are formed very rarely. Batista (1951) proposed the genus Viegasia to accommodate such fungi with $V$. cissampeli (Hansf.) Bat. as its type species. However, the ascospores in the present collection are smaller (14-21x5-9 vs. 21-25x11-14 $\mu \mathrm{m}$ ) (Hansford 1946; Müller \& Arx 1962). The genus Viegasia is reported here for the first time from India.

\section{REFERENCES}

Batista, A.C. (1951). Discussion on the genera Parmularia and Schneepia and election of new genus Viegasia. Boletin da Secretaria de Agricultura Industria e commercio 18: 29-34.

Hansford, C.G. (1946). Contributions towards the Fungus Flora of Uganda-VIII. New records. Proceedings of the Linnean Society of London 151: 138-212.

Hofmann, T.A. \& M. Piepenbring (2008). New species and records of Asterina from Panama. Mycological Progress 7: 87-98.

Hosagoudar, V.B. (2012). Asterinales of India. Mycosphere 2(5): 617852.

Hosagoudar, V.B. \& T.K. Abraham (2000). List of Asterina Lév. species based on the literature. Journal of Economic and Taxonomic Botany 24: 557-587.

Müller, E. \& J.A.V. Arx (1962). Die Gattungen der didymospores pyrenomycetes. Beter. Kryptogam. Der. Schweiz 11: 1-922.

Sydow, H. \& P. Sydow (1912). Fungi from the Islands of Palwan. Leaflet Philippine Botany 5: 1533-1547.

Sydow, H. \& P. Sydow (1920). Novae fungorum species-XVI. Annales Mycologici 18: 154-160.

Theissen, F.S.J. (1913). Die Asterina. Abh.kk. zool.-Bot. Ges., 130pp. 